\title{
UMA REFLEXÃO ACERCA DA TESE GAUCHETIANA DA SAÍDA DA RELIGIÃO
}

\author{
A REFLECTION ON THE GAUCHETIAN THESES CONCERNING THE "leaving of the religion"
}

\author{
JOSÉ ÁLVARO CAMPOS VIEIRA ${ }^{(*)}$
}

\begin{abstract}
RESUMO
No presente artigo procura-se refletir e problematizar a tese de Marcel Gauchet alusiva à saída da religião. No primeiro momento discorre-se acerca da concepção gauchetiana de religião. Na obra do filósofo, o termo religião remonta às sociedades primitivas. Nessas sociedades a coesão social advém de um poder absoluto e heterônomo. A essência da religião caracteriza-se, assim, pelo máximo da heteronomia. No segundo momento, examina-se o significado da máxima a respeito da saída da religião. Segundo Gauchet, a saída da religião ocorre quando nas sociedades humanas a heteronomia dá lugar à autonomia. A religião abandona aos poucos o lugar que ocupava nos primórdios. Com a modernidade, finda a era da religião, contudo o religioso não desaparece. A religião subsistirá no âmbito individual. No terceiro e último momento do artigo, problematiza-se o teor da tese de Gauchet a partir da leitura de alguns autores acerca de religião na contemporaneidade e da realidade sociorreligiosa brasileira. Indaga-se que a religião não pode ser pensada unicamente a partir do vínculo com a política. Ela interage, também, com outros elementos da vida humana, como a cultura. E quando a religião é ainda um componente cultural vigoroso, a tese da saída da religião se envolve de ambiguidade. PALAVRAS-Chave: Marcel Gauchet. Religião. Religioso. Cultura.
\end{abstract}

\section{ABSTRACT}

In this article we strive to reflect upon and problematize about Marcel Gauchet's thesis concerning the process of leaving Religion. In a first moment, we discuss the Gauchetian concept of Religion. In this philosopher's work the term Religion is connected to primitive societies. In these societies the social cohesion originated from an heteronomous absolute power. Hence, the essence of Religion was characterized by the utmost heteronomy. Secondly, we examine the meaning of the expression Leaving Religion. According to Gauchet, the Leaving Religion process occurs when, in human societies, the heteronomy gives place to autonomy. Religion gradually leaves the place it occupied in early times. With modernity, the age of Religion ends, however the religious does not disappear. Religion will endure in individual terms. In the third and final part of the article, we problematize the gist of Gauchet's thesis based upon the study of a few authors on contemporary Religion and on the Brazilian socioreligious reality. We interrogate that Religion cannot be explained solely by its bond with Politics. It also interacts with other elements of human life such as culture. And when Religion is still a vigorous cultural component, the thesis of leaving Religion becomes involved with ambiguity.

KEYWORDS:: Marcel Gauchet. Religion. Religious. Culture.

(*)Atualmente cursa o doutorado em Ciências da Religião, na Pontifícia Universidade Católica de Minas Gerais. Também na PUC Minas, fez especialização (2012) e mestrado (2014) na mesma área. E-mail: alvaroce@msn.com 


\section{INTRODUÇÃO}

Pretende-se neste artigo refletir e problematizar a tese de Marcel Gauchet relativa à saída da religião. No primeiro capítulo apresenta-se a concepção de religião, desse filósofo francês. Em sua obra, o conceito religião alude às sociedades primitivas, nas quais a coesão social se desenvolve graças a um poder absoluto e heterônomo. Desse modo, a essência da religião identifica-se com o máximo da heteronomia. No segundo capítulo do artigo, debruça-se sobre a tese da saída da religião. Segundo Gauchet, a saída da religião decorre à medida que a heteronomia diminui sua influência na vida social, dando lugar à autonomia. Nesse processo de transição, a religião abandona o lugar e a função que ocupava em seus primórdios. O desenvolvimento das sociedades humanas proporciona a supressão da religião, porém o religioso não desaparece. A religião perdurará, mas no âmbito individual. No terceiro e último capítulo contrapõe-se a tese de Gauchet com a visão de alguns estudiosos acerca de religião, contemporaneidade e realidade sociorreligiosa brasileira. Conclui-se que a religião não pode ser pensada unicamente a partir do vínculo com a política, tal como acontece com o filósofo francês. Admite-se que a religião interage com outros elementos da vida humana, os quais agregados entre si compõem a cultura de um povo. E quando a religião é um componente cultural expressivo na vida individual e coletiva de um povo, a tese da saída da religião se envolve de ambiguidade.

\section{CONCEPÇ̃̃o DE RELIGIÃO NA OBRA DE MARCEL GaUCHET}

Para se entender o sentido da tese de Marcel Gauchet da saída da religião faz-se necessário, primeiramente, ater-se à concepção de religião do filósofo. Para isso, transportar-se-á às sociedades humanas primitivas.

No imenso período de tempo da história da humanidade que antecede o ano 5000 a.C., os grupos humanos vivem segundo uma organização e um modo de viver que é chamado de sociedades primitivas. ${ }^{1}$ Nessas sociedades, a estrutura social e humana é perpetuada de geração em geração através dos mitos. Os mitos são criações coletivas e históricas próprias das sociedades desse tempo. É por meio dos mitos que os homens e as mulheres "primitivos" assimilam o sentido do mundo e da vida. O conteúdo dos mitos é transmitido de geração em geração e nele faz-se alusão a deuses e a ancestrais. Porque ninguém é credor,

\footnotetext{
${ }^{1}$ Está-se referindo a um período de tempo multimilenar. Segundo Gilberto Cotrim (2012), o tempo das sociedades primitivas corresponde ao período da história humana que ocorre 5,5 milhões de anos antes do surgimento da escrita, a qual surge há aproximadamente uns 4000 antes da era cristã.
} 
ninguém detém e ninguém se sobrepõe aos conteúdos mitológicos, os mitos permanecem de geração em geração. As sociedades primitivas são pautadas por um conservadorismo radical, pois tudo acontece conforme os mitos. São os mitos, portanto, que determinam toda e qualquer atividade individual e social (caça, coleta, relações de parentesco, etc.). Se o poder de coesão social advém dos mitos, são os mitos, então, que fundam as primeiras sociedades humanas. $\mathrm{E}$ se os mitos são as primeiras criações do saber religioso, logo, é a religião que funda a sociedade humana. Desse modo, entendemos as palavras de Marcel Gauchet: "A religião é criação da sociedade, mas criação que se confunde em última análise com o advento da própria sociedade." (GAUCHET, 2005, p. 52, tradução nossa). Todavia, o filósofo procura entender o que faz com que os homens e as mulheres dessa época criem a religião.

[...] em qual disposição da humanidade se funda essa instituição [a religião...] Mesmo que se rejeite a ideia de uma natureza religiosa do homem, ou de uma disposição natural para a metafísica, é preciso que haja algo como um substrato antropológico a partir do qual a experiência humana é suscetível de se instituir e de se definir sob o signo da religião. Nenhuma lógica política dá conta disso com que a religião vai se desdobrar, a saber, o investimento humano sobre o invisível. (FERRY; GAUCHET, 2008, p. 45).

Quando se percorre a história da humanidade, apercebe-se que o conflito é um fenômeno intrínseco à coletividade humana e que para se preservar a convivência entre os indivíduos e os diferentes grupos é fundamental e vital gerir o conflito. Segundo Gauchet (2003), nas sociedades primitivas o gerenciamento do conflito acontece em consequência da submissão coletiva ao sobrenatural. Nessa época existe uma sujeição radical dos homens e das mulheres ao sobrenatural. É o sobrenatural que determina o modo individual e coletivo de viver. Embora seja feita de modo inconsciente, os grupos humanos dessa época fazem uma escolha pelo sobrenatural porque só assim se torna viável a preservação da sociedade. Como afirma o filósofo: no fluxo da história "[...] existem "Decisões" sem decisores que redirecionam o curso das coisas." (GAUCHET, 2003, p. 87, tradução nossa). Consequentemente a essa escolha coletiva, tudo o que é integrado à vida humana se torna dependente, subordinado e controlado por outro e diferente mundo (em grego héteros) do qual procedem as leis (em grego nomos). Desse modo, a vida individual e social é determinada e conduzida pela heteronomia.

Fica evidente que para os homens e mulheres das sociedades primitivas o sentido da vida está fora deles mesmos, encontra-se em um Outro absoluto e heterônomo. Essa perspectiva impele Gauchet a pensar o estado original da 
religião pelo prisma da heteronomia. O máximo da heteronomia é, desse modo, a essência da religião. "A essência do religioso é [...] o estabelecimento de uma relação de despossessão entre o universo dos seres vivos-visíveis e seu fundamento.” (GAUCHET, 1985a, p. 43, tradução nossa). Na visão do autor, trata-se de uma despossessão completa, isto é, o ser humano recusa a própria autonomia e transfere o poder que detém a Outro, que é absoluto e heterônomo. Essa despossessão é a estrutura antropológica que habilita o ser humano a criar a religião. (GAUCHET, 1985a). A religião é, portanto, a vestimenta que os humanos criaram para gerir o conflito e preservar a convivência durante cerca de 5,5 milhões de anos de trajetória das sociedades primitivas. Desse ponto de vista, a religião é tida como uma criação cultural própria das sociedades primitivas.

Esse modo de conceber a religião leva Marcel Gauchet (1985a) a afirmar que existem duas características da religião que escapam a alguns estudiosos, que são: a religião como fenômeno histórico-cultural, isto é, a religião como algo com começo e fim; e a religião como escolha, e não como um fenômeno proveniente do constrangimento e do medo do ser humano frente às forças da natureza. Relativamente à ideia de se pensar a religião como fenômeno histórico-cultural, o autor acrescenta:

[...] há uma estrutura antropológica que faz com que o homem possa ser um ser de religião. Ele não o é necessariamente. Ele pôde sê-lo historicamente, durante a maior duração de seu percurso. Pode deixar de sê-lo, mas, nesse caso, esse potencial de religiosidade estará destinado a continuar. (FERRY; GAUCHET, 2008, p. 46).

Tal proposição desmorona a noção de que a religião é um elemento constitutivo da natureza humana. Além do mais, assegura Gauchet, “[...] a atitude religiosa me parece ser considerada como um possível ao lado de outros possíveis e não como uma necessidade constitutiva e permanente." (GAUCHET, 2002a, p. 89, tradução nossa). No olhar do autor, a religião é uma criação humana própria de uma época e que tende a se diluir à medida que os homens e as mulheres vão criando novos mecanismos de controle de coesão social. Adentra-se, assim, na tese gauchetiana alusiva à saída da religião.

\section{A TESE DA SAÍDA DA RELIGIÃO}

A tese da saída da religião de Marcel Gauchet assinala o fim da religião. Em sua obra, a religião é apresentada como "[...] um fenômeno histórico, quer dizer, definido por um começo e um fim, isto é, corresponde a uma era precisa da 
humanidade, à qual sucederá uma outra.” (GAUCHET, 1985a, p. 42, tradução nossa). A saída da religião é factual porque ao longo da história a heteronomia repercute cada vez menos na estrutura e na vida das sociedades humanas e, em contrapartida, a autonomia se consolida progressivamente como o novo fundamento. Por outras palavras, quanto mais as sociedades humanas se pautam pela autonomia, mais a religião se distancia do seu lugar primordial e que era central na vida das sociedades primitivas. $\mathrm{O}$ autor corrobora com estas palavras: “[...] por um lado, as religiões tiveram um papel determinante na maior parte das sociedades do passado, por outro, é necessário constatar que elas progressivamente perderam esse lugar, há alguns séculos [...].” (FERRY; GAUCHET, 2008, p. 40). Nessa afirmação, o filósofo alude ao lugar central e dominante da religião na época das sociedades primitivas.

$\mathrm{O}$ autor discorre acerca da saída da religião sob dois períodos de tempo. $\mathrm{O}$ primeiro corresponde à época que se inicia com o surgimento do Estado até o fim da Idade Média. Nesse período, Gauchet destaca três grandes rupturas que impulsionam determinantemente a transição da heteronomia para a autonomia. Tais rupturas são: a emergência do Estado, o período axial e a consolidação do cristianismo no Ocidente. São "três metamorfoses cruciais do Outro religioso. Três deslocamentos de uma amplitude fundamental do ponto de aplicação do invisível no seio do visível. Três reformulações da dívida dos homens avessas ao que está além deles [...].” (GUACHET, 1985b, p. 65, tradução nossa). O segundo período alude ao início da modernidade até à contemporaneidade. $O$ filósofo reflete a saída moderna da religião consoante três etapas distintas: a Reforma protestante, a Revolução francesa e o fortalecimento da autonomia decorrente da consciência histórica. Esses eventos "[...] são os três eixos da saída da religião, três eixos que ocorrem tal como sucessivas ondas do século XVI ao XIX.” (GAUCHET, 2002b, p. 336, tradução nossa). Debruça-se, em seguida, sobre esses eventos que, no pensamento de Gauchet, são decisivos para a consumação da saída da religião.

O Estado aparece na história humana há uns 5000 anos atrás. Com o surgimento do Estado irrompem mutações profundas na organização e na cosmovisão dos indivíduos desse tempo. Com o Estado o poder sobrenatural se incorpora em uma figura - o soberano/déspota. É esse que agora incorpora a Lei e é, doravante, o porta-voz dos deuses e dos ancestrais. O que era invisível o Outro absoluto e heterônomo - passa a ser visível. O Estado é o segundo estágio da despossessão religiosa. Realiza-se uma deslocação do ponto de aplicação do poder aglutinador social. Na visão de Gauchet (2005), o Estado é a primeira grande metamorfose do divino por se apresentar como o novo 
dispositivo de sentido. Com o aparecimento do Estado gera-se uma hierarquização na sociedade humana e instaura-se uma nova ordem social. A sociedade humana é fragmentada entre credores e devedores de sentido, entre dominantes e dominados. Para o filósofo, a humanidade sofre a maior mutação na sua dimensão espiritual com o surgimento do Estado, contudo, “[...] leva-se a crer que a instauração do Estado não corresponde à produção de uma dimensão social absolutamente inédita, mas à transformação de uma dimensão já presente no seio da sociedade [...] o prolongamento de uma sujeição primeira e de uma despossessão anterior [...].” (GAUCHET, 2005, p. 46, tradução nossa).

O período axial, que decorre entre os anos 800 a.C. e 200 a.C., é outro momento de enorme ruptura na história da humanidade. Conforme Marcel Gauchet (1985b), nesse período se realiza o despertar de diversas espiritualidades em diferentes povos, culturas e regiões do planeta. Surgem as primeiras figuras religiosas - Confúcio, Buda, Profetas de Israel, etc. - que apontam para uma subversão do status quo das sociedades de Estado, tendo como foco a justiça, a felicidade e a realização do gênero humano. É uma mudança revolucionária, uma “[...] radical e total transmutação do religioso, sob o signo da transcendência e da preocupação do verdadeiro mundo contra este mundo, [e uma] transvaloração das questões e das regras de vida que parecem surgir do nada [...]." (GAUCHET, 1985b, p.83, tradução nossa). A peculiaridade desse período histórico reside no surgimento de aspirações semelhantes em regiões distintas do planeta - China, Índia, Israel e Grécia - sem ter havido, supõe-se, uma interação entre os respectivos povos.

Outro evento de enorme incidência na passagem da heteronomia para a autonomia diz respeito ao cristianismo. O cristianismo preconiza a incorporação do divino em um homem - "Ele [Jesus Cristo] tinha a condição divina [...] esvaziou-se a si mesmo, assumindo a condição de servo e tornando-se semelhante aos homens.” (Fl 2,6-7) -, e sustenta a crença da presença do divino em cada homem e mulher - "Vocês não sabem que são templo de Deus e que o Espírito de Deus habita em vocês?” (1 Cor 3,16). O cristianismo é a religião da presença do Outro na interioridade. A comunicação com o Outro se dá, agora, no íntimo de cada ser humano. O poder sobrenatural, o Outro, depende, daí em diante, da escolha individual. Para Marcel Gauchet (1985c), com o cristianismo nos distanciamos mais da era da religião. Segundo o autor, o cristianismo é a religião da saída da religião na medida em que intensifica a autonomia do indivíduo e favorece, assim, a passagem da era da religião para a era do religioso, ou, por outras palavras, a transição da religião institucionalizada para a religião individualizada. 
Com a consolidação do cristianismo e o surgimento da modernidade no Ocidente, Marcel Gauchet (2002c) passa a se debruçar acerca da saída moderna da religião. O autor pensa a modernidade como o período de efetivação da saída da religião e consoante três etapas. A primeira alude à Reforma protestante e ao início da Filosofia política. O movimento reformista, liderado por Martinho Lutero, transfere a mediação com o Outro religioso (Deus), outrora concentrada na Igreja hierárquica (católica), para o indivíduo. O poder eclesiástico é abalado e, de modo consequente, o poder do Estado se fortalece através da figura do monarca. Gauchet nomeia essa etapa de teológico-política e situa-a entre os anos 1550 e 1650. A segunda etapa, intitulada teológico-jurídica, situada entre os anos 1650 e 1800, remonta à Revolução francesa e aos germes da democracia moderna. Tal revolução é preponderante para a formulação dos Direitos do Homem e do Cidadão, fortalecendo, por conseguinte, os direitos individuais e coletivos. No lugar do direito divino, proveniente de Deus, o direito natural passa a ser o eixo norteador. E, por último, a etapa da consciência histórica. Surge com a filosofia alemã, tendo Hegel como o filósofo mais influente. Essa etapa transcorre desde o início do século XIX. Os homens e as mulheres que são imbuídos pelos ideais da Revolução francesa - liberdade, igualdade e fraternidade - passam a cultivar uma nova consciência histórica. Para esses homens e mulheres torna-se evidente que a sociedade se faz na história e se constrói por meio do protagonismo deles mesmos. Irrompe a urgência de ruptura com velhas tradições, do engajamento no tempo e de projeção para um futuro almejado.

Analisando as mudanças decorrentes dos eventos acima mencionados - as "três metamorfoses cruciais do Outro religioso" e as três etapas que fomentaram a saída moderna da religião - percebe-se que à medida que o referencial heterônomo se torna menos influente na vida social, a função sociopolítica da religião diminui e tende a se extinguir. Desse modo, a religião se distancia cada vez mais do lugar que ocupava nas sociedades primitivas. A religião deixa de ditar a lei e de conduzir a vida social. De acordo com o filósofo, a saída da religião é um fenômeno recente que se desencadeou com o surgimento do Estado, isto é, há uns 5000 anos. O fim da religião estruturante se intensifica com o protagonismo do indivíduo moderno e, incontestavelmente, com o reconhecimento da consciência privada. E quando os homens e mulheres tomam consciência de seu papel e responsabilidade na história, realiza-se um passo significativo na saída da religião. Segundo a consciência histórica dos homens e das mulheres das sociedades modernas, "agora, cabe a eles determinar os valores e as regras de sua ação singular. Nada poderá desobrigá- 
los desta responsabilidade e ninguém lhes poderá ditá-la.” (GAUCHET, 2013, p. 577). Para Marcel Gauchet, a democracia é o novo mecanismo de coesão social que promove acentuadamente a saída da religião: "ela [democracia] é, na sua essência, uma ruptura com o modo de estruturação religiosa característico das sociedades humanas antes da nossa. A democracia é o poder dos homens substituindo a ordem definida pelos deuses ou exigida por Deus." (GAUCHET, 2013, p. 570).

Sob a ótica do filósofo (2004), a saída da religião é um fenômeno irreversível. A religião da forma como foi concebida pelos antepassados não tem mais valia para os homens e mulheres das sociedades atuais. (FERRY; GAUCHET, 2008). O tempo da religião tradicional findou, mas nem por isso a religião desaparecerá das sociedades. "[...] a saída da religião não significa, mesmo em curso, no fim da crença religiosa e no desaparecimento das instituições religiosas. Significa que seu estatuto muda e se desloca completamente." (GAUCHET, 2004, p. 236, tradução nossa). Na sua obra referencial - Le désenchantement du monde: une histoire politique de la religion - o autor afirma que "uma saída completa da religião é possível. Isso não significa que o religioso deve parar de falar aos indivíduos. Sem dúvida, aí mesmo é o lugar de se reconhecer a existência de um nível subjetivo ineliminável do fenômeno religioso onde [...] ocorre a experiência pessoal." (GAUCHET, 1985d, p. 393, tradução nossa). A religião permanecerá, mas agora restrita ao âmbito individual. Desse modo, a tese da saída da religião assinala que no decorrer da história, nomeadamente a partir do surgimento do Estado nas sociedades humanas, a religião se distancia cada vez mais do espaço público, ao perder de modo gradual seu poder de intervenção e de controle, e se restringe crescentemente ao espaço privado.

A religião "permanece atuante hoje e permanecerá no futuro, provavelmente. No entanto, o seu ponto de aplicação desloca-se, definitivamente, do social e do ético-político para o individual." (BARBOSA; HOTT, 2010, p. 75). Como diz Gauchet, "antes, elas [religiões] estruturavam a comunidade como um todo; agora se tornaram religiões do indivíduo, convicções da pessoa.” (GAUCHET, 2013, p.570). Se a religião perde sua função de estruturar a vida da sociedade, a saída da religião "[...] não implica o desaparecimento puro e simples da preocupação espiritual [...].” (FERRY; GAUCHET, 2008, p. 42). Na verdade, a busca de sentido é algo inerente ao ser humano e, independentemente da época da história que atravessa, ele é incessantemente "[...] convocado pelo invisível ou requisitado pela alteridade. Esses são os eixos dos quais ele tem originária e irredutivelmente a experiência." (FERRY; GAUCHET, 2008, p. 45). É 
congruente lembrar que a experiência do religioso acontece, de acordo com Gauchet, em meio a duas realidades.

A realidade tal como nos aparece, inesgotável multiplicidade de qualidades sensíveis, rede infinita de objetos distintos e de diferenças concretas, contém uma outra realidade: aquela que surge na mente quando se considera, além do visível, sua unidade e sua continuidade indiferenciada. (GAUCHET, 1985d, p. 395, tradução nossa).

Sob o ângulo do autor (1985d), após a saída da religião o religioso se manifesta em meio a três atividades: a) pela filosofia e/ou ciência, por intermédio das quais os humanos buscam uma inteligibilidade acerca do que acontece na realidade visível; $b$ ) pela estética, ou seja, não basta compreender o mundo, mas também senti-lo, pois existe algo que está além do sensível, e c) pela psicologia, a qual se debruça sobre o que somos para nós mesmos. Nós, humanos, não nos contentamos em ser o que somos. Tendemos sempre a ser mais. Para Gauchet (1985d), por meio da operação dessas três atividades continua-se a caminhar segundo o núcleo antropológico a partir do qual a humanidade criou a religião.

Em suma, Marcel Gauchet afirma por meio da tese da saída da religião que a era da religião terminou. $\mathrm{Na}$ atualidade existem apenas elementos religiosos, mas não religião. O que se vive e é presenciado na contemporaneidade são vestígios da religião. A religião teve o seu fim. Perdeu sua força e sua influência no corpo social, todavia, o religioso permanece. A religião saiu do seu lugar sociopolítico e se reduz, agora, à esfera individual. Passa-se da era da religião para a era do religioso.

\section{RELIGIÃO, CONTEMPORANEIDADE E PROBLEMATIZAÇÃO DA TESE}

Neste momento do artigo procura-se problematizar o conteúdo da tese de Marcel Gauchet mediante a contribuição de alguns autores que se debruçam acerca da realidade sociorreligiosa brasileira contemporânea. A partir dos dados do censo de 2010, alguns autores, tais como Pierre Sanchis, Faustino Teixeira, Clara Mafra, Antônio Pierucci, Marcelo Camurça, Regina Novaes, Leila Amaral, entre outros, discorrem acerca da realidade sociorreligiosa brasileira e mencionam, quando oportuno, o parecer de outros estudiosos de religião no contexto mundial atual. No conjunto das análises percebe-se elementos consonantes com a tese de Gauchet: a desinstitucionalização e a individualização da experiência religiosa, a ambiguidade do uso de categorias tradicionais no contexto sociorreligioso atual, entre outros. Todavia, 
relativamente à ideia-chave da tese do filósofo francês, o qual ressalta o fim da era da religião, não se encontra eco na reflexão dos autores supracitados.

Para Peter Berger, citado por Faustino Teixeira (2013), “[...] o que ocorre de fato é uma singular e vigorosa 'ressurgência' da religião, que ganha uma fisionomia particular nas pujantes presenças tanto da renovação islâmica como da irradiação evangélica, sobretudo pentecostal.” (TEIXEIRA, 2013, p. 20). As mudanças contemporâneas que ocorrem na religião apontam para a perda da força das instituições religiosas. (BERGER, 2001). Para Danièle Hervieu-Léger (2008), as mudanças que ocorrem na atualidade remetem a um processo de reconfiguração da religião e de recomposição do campo religioso contemporâneo. Essas análises sugerem que as mudanças atuais não apontam “[...] para o enfraquecimento e o colapso da religião, mas para uma situação de perda da força das instituições religiosas e de recomposição do campo religioso. Quer para Peter Berger, quer para Danièle Hervieu-Léger, a modernidade não conduz ao declínio da religião.” (VIEIRA, 2016, p. 77).

$\mathrm{Na}$ visão de Berger, a religião "[...] tem sido uma característica perene da humanidade (isto é uma afirmação antropológica, e não teológica - um filósofo agnóstico ou mesmo ateu pode muito bem concordar com ela).” (BERGER, 2001, p. 19). Nos estudos desses autores subjaz a ideia de que existe uma religião essencial que permanecerá sem rupturas na história da humanidade. Essa ideia é incabível na obra de Marcel Gauchet. Outros autores seguem a linha de que o que ocorre é uma transformação e não o fim da religião. Para Frédéric Lenoir, mencionado por Faustino Teixeira, "as religiões continuarão se transformando e sofrendo os efeitos da Modernidade [...]" (TEIXEIRA, 2013, p. 21). Todavia, ainda segundo Lenoir, essas transformações se processarão não "[...] como no passado, dentro de uma tradição imutável ou de um dispositivo institucional normativo." (TEIXEIRA, 2013, p. 21), mas por meio da afirmação crescente da individualização da experiência religiosa. Como visto anteriormente, essa individualização da experiência religiosa se reflete também no pensamento de Gauchet.

A "ressurgência" do religioso é rotulada por Pierre Sanchis de mistério sociológico, pois enquanto certos estudos apontam para o esvaziamento, a realidade assinala a multiplicação de experiências religiosas. Devido a esse desencontro entre a realidade e alguns estudos realizados, o fato religioso é visto pelo antropólogo na perspectiva da complexidade,

[...] não só porque, ao lado e articuladamente com a secularização, detecta-se certa reemergência do fator sagrado, na vida social e na experiência individual mas porque [...] as formas e significações das realidades presentes tendem a 
diferir daquelas que existiam nas precedentes análises sob as mesmas categorias. $\mathrm{E}$ até quando as realidades tradicionais perduram, ou se reafirmam por conta própria, é possível que as significações novas refluam sobre as antigas, articulando-se com elas para inflectir-lhes tacitamente o sentido. (SANCHIS, 2013, p. 12).

Frente a essa complexidade, Sanchis alerta os estudiosos para o cuidado no uso de categorias tradicionais visto que a realidade sociorreligiosa atual é atravessada por significações novas e por grandes mudanças civilizacionais. $\mathrm{O}$ uso ambíguo das categorias tradicionais é também uma problemática colocada por Gauchet (2008) no diálogo que trava com Luc Ferry. Afirma o filósofo: "Acredito que Luc Ferry se entregue a um transporte indevido de categorias do passado religioso para a ultramodernidade, para estabelecer uma continuidade que me parece amplamente fictícia. (FERRY; GAUCHET, 2008, p. 48). Essa dificuldade é colocada, também, por Barbosa e Lott, quando ambos se debruçam sobre o debate mencionado antes. Escrevem esses autores: "Como compreender essas manifestações atuais? Qual seria o vocabulário mais adequado para tratar e designar o religioso hoje? Como sugere Marcel Gauchet, devemos, certamente, repensar as categorias advindas da religião.” (BARBOSA; LOTT, 2010, p.74). Que categorias devem ser usadas na análise dos fenômenos da atualidade, no caso os de âmbito religioso, é uma questão efetivamente a ser considerada pelos estudiosos.

Entre as mudanças civilizacionais destacadas por Sanchis, duas se adequam harmonicamente à tese de Gauchet: a emergência do indivíduo na manutenção do religioso e na criação de sentido, e a desinstitucionalização crescente da experiência religiosa. Essas ideias foram apresentadas no final do item anterior, quando abordou-se a tese da saída da religião. Entretanto, no que diz respeito à relação religião e política entre esses autores, existe uma dissonância. Se para Gauchet o divórcio entre religião e política é algo já concretizado, na visão de Pierre Sanchis religião e política é, na atualidade, uma temática relevante e que deve ser considerada pelos estudiosos do fenômeno religioso. Por um lado, ao nível local, grupos religiosos persistem em atuar no espaço público conforme as determinações de sua tradição religiosa.

[...] a promoção de justiça e liberdade não deixa de pautar a perspectiva de numerosos grupos religiosos [... e] grupos organizados e instituições em peso reafirmam sua presença, organizada e denominacionalmente explícita, no espaço público, em função de interesses diretamente institucionais, mas também da promoção de valores próprios, considerados como universais, no campo, por exemplo, da bioética e dos arranjos sociossexuais. (SANCHIS, 2013, p. 15). 
Por outro lado, o papel mediador das religiões na construção da paz social é fundamental e urgente: “[...] o papel das religiões nesta tarefa, a julgar pela atualidade internacional, instaura-se de novo no primeiro plano. Como problema. E problema político [...] apesar de certas aparências, não se romperam os laços entre o mundo de cima e a ordenação do nosso, terrenal.” (SANCHIS, 2013, p. 16). Na visão de Clara Mafra (2013), a religião, por meio de seus seguidores, continua a intervir na vida pública: “[...] os coletivos religiosos são atores relevantes não apenas na vida privada dos cidadãos, mas na vida pública, muitas vezes constituindo-se como aliados fundamentais para a criação e/ou manutenção do Estado laico ou secular.” (MAFRA, 2013, p. 41). Neste ponto verifica-se um distanciamento substancial de Gauchet com Sanchis e Clara Mafra. Isso incita a discorrer mais e criticamente acerca do pensamento do filósofo francês.

Julga-se importante ponderar que Gauchet constrói uma máxima acerca de religião - a saída (fim) da religião - tendo como foco o lugar da religião na vida pública da coletividade. O filósofo francês afirma que desde o surgimento do Estado se iniciou na história humana a saída ou o fim da religião. Na atualidade, conforme Gauchet, a religião se reduz à vida privada e não intervém mais na vida pública. Compreende-se esse posicionamento porque o autor tem como eixo a relação religião e política na construção de sua argumentação. No entanto, entende-se que a religião não pode ser pensada unicamente a partir do vínculo com um elemento da vida humana, no caso a política. A religião interage com outros elementos da vida humana, por exemplo, a cultura. Aliás, a cultura é o sistema que integra os diversos elementos que compõem a vida de um indivíduo e de um povo. A cultura não é um elemento adjacente a outros, tais como política, religião, economia e outros, mas agregador desses. Para o antropólogo Roque de Barros Laraia (2009), a cultura é algo que deve ser considerado na análise dos fenômenos humanos uma vez que todos os indivíduos e todo o povo são resultado e se comportam segundo uma história cultural. Por esse motivo, quando se pensa a religião a partir da cultura, provoca-se a analisar seu lugar não apenas no âmbito individual, mas principalmente no coletivo.

No Brasil, por exemplo, as religiões espíritas e de culto afro "[...] podem ter pouca expressão política, mas têm uma enorme influência cultural." (MAFRA, 2013, p. 42). Embora na sociedade brasileira atual nenhuma religião determine a vida política da coletividade, essa mesma coletividade é influenciada com vigor por elementos culturais religiosos. Isso revela que a religião, mesmo podendo estar isenta da esfera política, continua participando da vida da coletividade, ou 
seja, da vida pública. Ao referir-se à saída da religião de Gauchet, Leila Amaral assevera que "a idade da religião como estruturante terminou; no entanto, seria ingênuo acreditar que terminamos com a religião como cultura.” (AMARAL, 2013, p. 296). Portanto, torna-se ambíguo falar-se de saída (fim) da religião em certas sociedades quando no alicerce da cultura a religião é ainda um componente robusto. Isso vale, também, para a sociedade da qual Gauchet se integra. Ao se debruçar acerca da realidade sociorreligiosa francesa, Philippe Portier, também citado por Faustino Teixeira (2013), comenta que se sucedem "[...] dois fenômenos simultâneos: a dessubstancialização da civilização católica e o reencantamento da civilização republicana.” (TEIXEIRA, 2013, p. 20). Quer dizer, Portier não alude ao fim efetivo da religião.

Outros elementos podem ser considerados para aprofundar a temática religião e cultura. Os dados censitários do Brasil revelam "[...] a perda de consistência do "Brasil católico", sem uma referência mais consensual do catolicismo como constituidor da "totalidade" [...]" (MAFRA, 2013, p. 43). Observa-se, no Brasil, a perda da hegemonia de uma religião, mas não da religião. Aliás, e no parecer de Pierucci, se tratando de religião "[...] a coisa por aqui [no Brasil] anda mesmo efervescente." (PIERUCCI, 2013, p. 51). Por outras palavras, o povo brasileiro continua imerso entre várias religiões e inúmeras experiências religiosas. Mesmo entre os indivíduos que afirmam não ter religião, o fator da cultura religiosa é preponderante. "Entendendo os semreligião como "religiosos sem instituição" isso não discreparia da "tradição religiosa" do país, eles apenas expressariam no Brasil o processo de "desfiliação religiosa" [...]." (CAMURÇA, 2013, p. 81). Contudo, entende-se que o fenômeno dos sem religião não pode ser interpretado apenas sob o viés da crise de pertença institucional.

Regina Novaes afirma que as análises acerca dos sem religião são ainda “[...] bastante presas a velhas teorias [...] o desafio, teórico e prático, é compreender a presença dos jovens sem religião sem desembocar obrigatoriamente na lógica dos pertencimentos/rompimentos institucionais.” (NOVAES, 2013, p. 188). O fenômeno dos sem religião assinala o descrédito de indivíduos não só na instituição religiosa, mas também nos elementos fundantes da religião, ou seja, na doutrina e nas crenças religiosas. (VIEIRA, 2016). Esses indivíduos não são apenas os ateus e agnósticos, mas também os sem religião que romperam em simultâneo com a instituição e a religião, e preservam a fé em algo transcendente. Do ponto de vista desse artigo, o fenômeno brasileiro dos sem religião com fé, que são 95,17\% do total dos sem religião (IBGE, 2013), ecoa nitidamente duas ideias subjacentes à tese de Marcel Gauchet, a saber, o fim, 
para muitos indivíduos, da religião tradicional/institucional, e o deslocamento da religião para o âmbito privado.

Existe uma vaga de autores que ao refletirem acerca do lugar da religião na contemporaneidade se aproximam da ideia gauchetiana da saída da religião, no sentido de enfraquecimento, de crise e de fim da religião. ${ }^{2}$ No olhar de Marià Corbí (2011), o número incomensurável de experiências, a disseminação de grupos religiosos e a crescente fragmentação do cenário religioso são fenômenos que assinalam a crise que atravessa as religiões tradicionais. "As religiões têm uma relação intrínseca com as sociedades estáticas pré-industriais. Esta é uma constatação importante. Como regra geral, onde há esse tipo de sociedades, a religião existe, e onde esse tipo de sociedades desaparece, a religião [...] tende a desaparecer." (CORBÍ, 2010, p. 167). A Comisión Teológica Internacional de la EATWOT declara que a crise que se desenrola se refere "[...] à própria natureza das "religiões" e à incapacidade crescente que elas experimentam em se adaptarem à profunda mudança cultural que está em curso." (COMISIÓN TEOLÓGICA INTERNACIONAL DE LA EATWOT, 2016, tradução nossa). José María Vigil compartilha dessa mesma visão e afirma que não se trata de uma crise do cristianismo, mas de uma crise na "[...] forma da humanidade ser religiosa que prevaleceu desde o início da sociedade agrária." (VIGIL, 2010, p. 35). Claro que alguns conceitos usados por esses ou por outros autores que se avizinham ou se harmonizam com a tese de Gauchet deveriam ser delimitados para se garantir uma maior coerência ao estudo comparativo das diferentes reflexões, mas reconhece-se que essa tarefa exige uma análise que vai além do objetivo deste artigo. Contudo, considera-se que a crise contemporânea da religião é um fato reconhecido entre vários teólogos, filósofos, estudiosos da religião e cientistas sociais da atualidade.

\section{CONSIDERAÇÕES FINAIS}

Quando Marcel Gauchet fala categoricamente que não existe mais religião e que a era da religião findou, avalia-se essa posição de certo modo arbitrária por se encontrar diante de proposições formuladas a partir de uma concepção de religião muito peculiar e própria de um autor. Na ocasião em que elabora uma

\footnotetext{
2 Conforme esses autores, as mudanças acentuadas e ininterruptas que ocorrem e a crise profunda de sentido que afeta todos os aspectos da vida humana e social na atualidade assinalam uma situação profunda de crise de não apenas uma religião, mas das religiões agrárias. Esses autores são: Carlos Palacio (2016), José Amando Robles (2016), José María Vigil (2010), Jung Mo Sung (2016), Marià Corbí (2010), Thomas Berry (2016), os membros da Associação Ecumênica de Teólogos do Terceiro Mundo / Comisión teológica internacional de la EATWOT (2016), entre outros.
} 
leitura crítica da tese gauchetiana, Paul Valadier faz menção à peculiaridade e à ambiguidade da concepção de religião de Gauchet com estas palavras:

Em nome de quê um etnólogo se atribuiria o direito de falar de "religião pura"? Nós não saberemos nada disso. Você mesmo fala da "essência do religioso" [...] mas encontraríamos hoje muitos especialistas informados para circunscrever assim alegremente uma "essência do religioso"? (GAUCHET, 2002a, 73, tradução nossa).

Mais adiante, nessa mesma análise crítica, Paul Valadier alega que Gauchet apresenta conclusões arbitrárias, pelo fato de partir de premissas incabíveis: "[...] cai em logro tendo uma primeira vez identificando religião e sociedade primitiva, tendo uma segunda vez identificando sociedade primitiva e fixação no e pelo imutável, tendo enfim decidido arbitrariamente que a figura perfeita da religião aí se encontraria [...].” (GAUCHET, 2002a, 76, tradução nossa). Compartilha-se da leitura de Paul Valadier, valendo-se da realidade sociorreligiosa brasileira e da relação basilar entre religião e cultura.

No que concerne às análises realizadas acerca de religião, contemporaneidade e realidade sociorreligiosa brasileira, julga-se que no lugar de saída (fim) da religião, talvez seja mais adequado falar-se de enfraquecimento da religião institucional e de fortalecimento de religiosidades, ou religiões individuais. É visível que a forma institucional da religião que vinha determinando a vida dos indivíduos vem se enfraquecendo à medida que as sociedades prosseguem na história, especificamente as do Ocidente. É claro que a religião institucional não mais determina a vida individual e social, mas elementos religiosos ainda permeiam a vida cultural dos indivíduos e das coletividades dessas sociedades. Será este tempo que se atravessa um interregno entre dois reinados, ou seja, entre o declínio do reinado da instituição e a consolidação do reinado da individualização? Difícil responder, pois entre esses reinados e neste tempo de mudanças que se vivencia existe um vasto campo mutável e incerto de diferentes culturas que influem determinantemente na vida de toda sociedade humana.

Este momento histórico que assinala o declínio de um reinado (instituição religiosa) e o fortalecimento de outro reinado (individualização da experiência religiosa) é pautado por diversas culturas que se confrontam permanentemente e que moldam sem fim os indivíduos e a coletividade. Nesse enfrentamento de culturas não há lógica e exatidão. Tudo é contingente e imprevisível. O que resultará do enfraquecimento de um reinado e do irrompimento do outro, o tempo ou a história revelará. Nesse contexto, a todo o momento mutável e incerto, qualquer afirmação ou tese peremptória e/ou imperativa é 
problemática. Em vista disso, falar de fim da religião configura-se não como uma expressão incorreta, mas ambígua, já que a(s) cultura(s) que pautam a realidade brasileira mantêm vigorosamente elementos religiosos. Afirmar o fim de certos costumes, tradições e instituições, pode ser compreensível, mas falar do fim de algo que é ainda cultural, no caso a religião, parece arbitrário. Não obstante, crê-se que a tese de Marcel Gauchet ajuda, indiscutivelmente, a pensar as mudanças sociorreligiosas que ocorrem na atualidade e provoca todo estudioso a discorrer terminantemente acerca da pergunta - Assistimos ao fim da era da religião?

\section{REFERÊNCIAS}

AMARAL, Leila. Cultura religiosa errante. In: TEIXEIRA, Faustino; MENEZES, Renata (org.). Religiões em movimento. O censo de 2010. Petrópolis: Vozes, 2013, p. 295310 .

BARBOSA, Wilmar do Valle; LOTT, Henrique Marques. "O religioso após a religião": um debate entre Marcel Gauchet e Luc Ferry. Horizonte, Belo Horizonte, v. 8, n. 19, p. 71-100, out./dez. 2010.

BERGER, Peter. A dessecularização do mundo: uma visão global. Religião e Sociedade, Rio de Janeiro, v. 21, p.9-23, 2001.

BERRY, Thomas. Lo divino y nuestro actual momento revelador. Disponível em: <http://www.servicioskoinonia.org/relat/390.htm>. Acesso em: 15 out. 2016.

CAMURÇA, Marcelo Ayres. O Brasil religioso que emerge do Censo de 2010: consolidações, tendências e perplexidades. In: TEIXEIRA, Faustino; MENEZES, Renata (org.). Religiões em movimento. O censo de 2010. Petrópolis: Vozes, 2013. p. 63-87.

CARTA AOS FILIPENSES. In: A BÍBLIA: edição pastoral. São Paulo: Paulinas, 2002.

COMISIÓN TEOLÓGICA INTERNACIONAL DE LA EATWOT. Hacia un Paradigma Pos-religional. Propuesta Teológica. Disponível em:

<http://www.servicioskoinonia.org/relat/424.htm>. Acesso em: 15 out. 2016.

CORBÍ, Marià. El destino de las nuevas sociedades industriales está sólo en nuestras manos. Horizonte, Belo Horizonte: PUC Minas, v.9, n.23, p.821-838, out./dez. 2011.

CORBÍ, Marià. Para uma espiritualidade leiga sem crenças, sem religiões, sem deuses. São Paulo: Paulus, 2010.

COTRIM, Gilberto. História Global: Brasil e geral. 10. ed. São Paulo: Saraiva, 2012.

FERRY, Luc; GAUCHET, Marcel. Depois da religião. O que será do homem depois que a religião deixar ditar a lei? São Paulo: Difel, 2008. 
GAUCHET, Marcel. Fin de la religion? In: GAUCHET, Marcel. La démocratie contre ellemême. Paris: Gallimard, 2002c, p. 27-66.

GAUCHET, Marcel. La dette du sens et les racines de L'État. Politique de la religion. In: GAUCHET, Marcel. La condition politique. Paris : Gallimard, 2005. p. 45-89.

GAUCHET, Marcel. Le religieux après la religion. In: GAUCHET, Marcel. Le désenchantement du monde: une histoire politique de la religion. Paris: Gallimard, 1985d. p. 393-407.

GAUCHET, Marcel. Les metamorfoses du divin : origine, sens et devenir du religieux. In: GAUCHET, Marcel. Le désenchantement du monde: une histoire politique de la religion. Paris: Gallimard, 1985a. p. 39-62.

GAUCHET, Marcel. Les trois vagues de la modernité. In: GAUCHET, Marcel. La démocratie contre elle-même. Paris: Gallimard, 2002b. p. 336-340.

GAUCHET, Marcel. Quel rôle pour les institutions religieuses dans des sociétés sorties de la religion? In: GAUCHET, Marcel. Un monde désenchanté? Paris: Les Éditions de l'Atelier, 2004. p. 235-249.

GAUCHET, Marcel. Religião, ética e democracia. Numen, Juiz de Fora, v. 16, n.1, 2013. p. 567-580.

GAUCHET, Marcel. Sur la religion: un échange avec Paul Valadier. In: GAUCHET, Marcel. La démocratie contre elle-même. Paris: Gallimard, 2002a. p. 67-90.

GAUCHET, Marcel. La Leçon de L'ethnologie. In: GAUCHET, Marcel. La condition historique. Paris : Gallimard, 2003. p. 79-100.

GAUCHET, Marcel. L'État, transformateur sacral. In: GAUCHET, Marcel. Le désenchantement du monde: une histoire politique de la religion. Paris: Gallimard, 1985b. p. 63-89.

GAUCHET, Marcel. Puissances du sujet divin. La religion de la sortie de la religion. In: GAUCHET, Marcel. Le désenchantement du monde: une histoire politique de la religion. Paris: Gallimard, 1985c. p. 197-255.

HERVIEU-LÉGER, Danièle. O fim das identidades religiosas herdadas. In: HERVIEULÉGER, Danièle. O peregrino e o convertido. Petrópolis, Vozes, 2008. p. 57-80.

INSTITUTO BRASILEIRO DE GEOGRAFIA E ESTATÍSTICA. Tabela 137 - População residente por religião. Disponível em:

$<$ www.sidra.ibge.gov.br/bda/tabela/listabl.asp? $\mathrm{z}=\mathrm{cd} \& \mathrm{O}=2 \& \mathrm{i}=\mathrm{P} \& \mathrm{c}=137>$. Acesso em: 15 out. 2016.

LARAIA, Roque de Barros. Cultura: um conceito antropológico. 24. ed. Rio de Janeiro, Zahar, 2009.

MAFRA, Clara. O que os homens e as mulheres podem fazer com os números que fazem coisas. In: TEIXEIRA, Faustino; MENEZES, Renata (org.). Religiões em movimento. O censo de 2010. Petrópolis: Vozes, 2013, p. 37-47. 
NOVAES, Regina. Jovens sem religião: sinais de outros tempos. In: TEIXEIRA, Faustino; MENEZES, Renata (org.). Religiões em movimento. O censo de 2010. Petrópolis: Vozes, 2013. p. 175-190.

PALACIO, Carlos. Novos paradigmas ou fim de uma era teologica? Disponível em: <http://www.servicioskoinonia.org/relat/227p.htm>. Acesso em: 15 out. 2016.

PIERUCCI, Antônio Flávio. O crescimento da liberdade religiosa e o declínio da religião tradicional: a propósito do Censo de 2010. In: TEIXEIRA, Faustino; MENEZES, Renata (org.). Religiões em movimento. O censo de 2010. Petrópolis: Vozes, 2013. p.49-61.

PRIMEIRA CARTA AOS CORÍNTIOS. In: A BÍBLIA: edição pastoral. São Paulo: Paulinas, 2002.

ROBLES, J. Amando Robles. Repensar la religión. La religión ante la cultura actual. Disponível em:<http://www.servicioskoinonia.org/relat/344p.htm>. Acesso em: 15 out. 2016.

SANCHIS, Pierre. Prefácio. In: TEIXEIRA, Faustino; MENEZES, Renata (org.).

Religiões em movimento. O censo de 2010. Petrópolis: Vozes, 2013, p. 11-16.

SUNG, Jung Mo. A crise do cristianismo e a crise do mundo. Disponível em: <http://www.servicioskoinonia.org/relat/247p.htm>. Acesso em: 15 out. 2016.

TEIXEIRA, Faustino. O Censo de 2010 e as religiões no Brasil: esboço de apresentação. In: TEIXEIRA, Faustino; MENEZES, Renata (org.). Religiões em movimento. $O$ censo de 2010. Petrópolis: Vozes, 2013, p.17-35.

VIEIRA, José A. C. Os sem religião. Aurora de uma espiritualidade não-religiosa. Fortaleza: Parole, 2016.

VIGIL, José María. A crise da vida religiosa na Europa do século XXI, tema de reflexão para a vida religiosa latino-americana. Ciberteologia, São Paulo, ano VI, n. 31, p. 2942, set./out. 2010. 